\title{
Differential Regulation of Gonadotropin-Releasing Hormone Neuron Activity and Membrane Properties by Acutely Applied Estradiol: Dependence on Dose and Estrogen Receptor Subtype
}

\author{
Zhiguo Chu, ${ }^{1}$ Josefa Andrade, ${ }^{1}$ Margaret A. Shupnik, ${ }^{1,2}$ and Suzanne M. Moenter ${ }^{1,3}$ \\ Departments of ${ }^{1}$ Medicine, ${ }^{2}$ Molecular Physiology and Biological Physics, and ${ }^{3}$ Cell Biology, University of Virginia, Charlottesville, Virginia 22908
}

\begin{abstract}
Gonadotropin-releasing hormone (GnRH) neurons are critical to controlling fertility. In vivo, estradiol can inhibit or stimulate GnRH release depending on concentration and physiological state. We examined rapid, nongenomic effects of estradiol. Whole-cell recordings were made of GnRH neurons in brain slices from ovariectomized mice with ionotropic GABA and glutamate receptors blocked. Estradiol was bath applied and measurements completed within $15 \mathrm{~min}$. Estradiol from high physiological (preovulatory) concentrations (100 pм) to $100 \mathrm{~nm}$ enhanced action potential firing, reduced afterhyperpolarizing potential (AHP) and increased slow afterdepolarization amplitudes (ADP), and reduced $I_{\mathrm{AHP}}$ and enhanced $I_{\mathrm{ADP}}$. The reduction of $I_{\mathrm{AHP}}$ was occluded by previous blockade of calcium-activated potassium channels. These effects were mimicked by an estrogen receptor (ER) $\beta$-specific agonist and were blocked by the classical receptor antagonist ICI182780. ER $\alpha$ or GPR30 agonists had no effect. The acute stimulatory effect of high physiological estradiol on firing rate was dependent on signaling via protein kinase A. In contrast, low physiological levels of estradiol (10 pM) did not affect intrinsic properties. Without blockade of ionotropic GABA and glutamate receptors, however, $10 \mathrm{pm}$ estradiol reduced firing of GnRH neurons; this was mimicked by an $\mathrm{ER} \alpha$ agonist. ER $\alpha$ agonists reduced the frequency of GABA transmission to GnRH neurons; GABA can excite to these cells. In contrast, ER $\beta$ agonists increased GABA transmission and postsynaptic response. These data suggest rapid intrinsic and network modulation of $\mathrm{GnRH}$ neurons by estradiol is dependent on both dose and receptor subtype. In cooperation with genomic actions, nongenomic effects may play a role in feedback regulation of $\mathrm{GnRH}$ secretion.
\end{abstract}

\section{Introduction}

Gonadotropin-releasing hormone ( $\mathrm{GnRH}$ ) neurons form the final common pathway for the central regulation of fertility. $\mathrm{GnRH}$ is typically released in pulses of varying frequencies (Clarke and Cummins, 1982; Levine et al., 1982; Levine and Duffy, 1988; Moenter et al., 1991, 1992, 2003). In addition to episodic release, in females, a surge mode of GnRH release also exists in which neural activity and hormone release are elevated for hours (Döcke and Dörner, 1965; Moenter et al., 1991; Christian et al., 2005). The gonadal steroid estradiol is a critical feedback regulator of GnRH neurons and is involved in both suppression of episodic release (negative feedback) and induction of the surge mode of release (positive feedback) (Döcke and Dörner, 1965; Herbison, 1998). Estradiol feedback may involve both changes in synaptic transmission to $\mathrm{GnRH}$ neurons and altered intrinsic

\footnotetext{
Received Jan. 22, 2009; revised March 16, 2009; accepted March 25, 2009.

This work was supported by National Institutes of Health Grants HD34860 and HD41469. Portions of this work were presented in abstract form at the 2007 Endocrine Society and 2007 and 2008 Society for Neuroscience Meetings. We thank Debra Fisher for excellent technical assistance, Dr. Houng-Wei Tsai for advice on estradiol treatments, and Catherine Christian, Justyna Pielecka, Pei-San Tsai, Jianli Sun, Alison Roland, and Peilin Chen for editoria comments.

Correspondence should be addressed to Suzanne M. Moenter, Departments of Medicine and Cell Biology, P.0. Box 800578, University of Virginia, Charlottesville, VA 22908. E-mail: Moenter@virginia.edu.

D0I:10.1523/JNEUROSCI.0352-09.2009

Copyright $\odot 2009$ Society for Neuroscience $\quad 0270-6474 / 09 / 295616-12 \$ 15.00 / 0$
}

excitability (DeFazio et al., 2002; Nunemaker et al., 2002; Abe and Terasawa, 2005; Chu and Moenter, 2006; Wintermantel et al., 2006; Christian and Moenter, 2007; Romanò et al., 2008).

Estradiol may act via different receptors with different time courses and mechanisms (Filardo and Thomas, 2005; Heldring et al., 2007; Woolley, 2007). In the classical mechanism, estradiol binds to the $\alpha$ or $\beta$ isoform of the estrogen receptor (ER), which binds to estrogen-response elements and alters gene transcription (Glass, 1994). Nonclassical action of $\mathrm{ER} \alpha$ and $\mathrm{ER} \beta$ are possible through alternative response elements in DNA (Sabbah et al., 1999; Kushner et al., 2000) or rapid changes in signaling cascades (Zhou et al., 1996; Nethrapalli et al., 2001). Alternative ERs have also been proposed, including a G-protein-coupled receptor, GPR30 (Revankar et al., 2005), ER-X (Toran-Allerand et al., 2002), and mER (Qiu et al., 2003). All of these mechanisms operate in the CNS.

The expression of estrogen receptors by GnRH neurons is controversial. Iodinated estradiol is concentrated by these cells, suggesting high affinity binding (Hrabovszky et al., 2000). In samples from brain, messenger RNA and protein for ER $\beta$ but not $\mathrm{ER} \alpha$ have been detected in these cells (Skynner et al., 1999; Herbison et al., 2001; Hrabovszky et al., 2001). ER $\alpha$ transcript has been identified in immortalized GT1 GnRH neuronal cell lines and cultures of embryonic GnRH neurons (Roy et al., 1999; Na- 
varro et al., 2003). Both ER subtypes have important reproductive effects; $\mathrm{ER} \alpha$ knock-out (KO) mice are infertile and $\mathrm{ER} \beta \mathrm{KO}$ are subfertile (Couse and Korach, 1999; Wintermantel et al., 2006). Both $\mathrm{ER} \alpha$ and $\mathrm{ER} \beta$ have been implied in rapid effects of estradiol on GnRH neurons (Abrahám et al., 2003, 2004; Temple et al., 2004; Abe and Terasawa, 2005), although a recent report suggests a pure $\operatorname{ER} \alpha / \operatorname{ER} \beta$ antagonist fails to block some rapid effects, indicating alternative mechanisms may exist (Abe et al., 2008).

Here, we examined how estradiol acutely affects GnRH neuron properties using whole-cell electrophysiology. We show that both stimulatory and inhibitory effects are elicited by rapid estradiol application, that the direction of response depends on dose and receptor subtype, and that different neurobiological mechanisms are engaged.

\section{Materials and Methods}

Animals. Adult (2-3 months of age) female mice expressing enhanced green fluorescent protein (GFP; Clontech) under the control of the GnRH promoter were used to facilitate identification of $\mathrm{GnRH}$ neurons (Suter et al., 2000). Mice were maintained under a 14 h light:10 h dark photoperiod with Harlan 2916 chow and water available ad libitum. To avoid the confounding effects of ovarian hormone changes during the estrous cycle, mice were ovariectomized (OVX) under isoflurane (Burns Veterinary Supply) anesthesia 5-9 d before experimentation; time after gonadectomy did not affect results. The long-acting local anesthetic bupivacaine $(0.25 \%$; Abbott Laboratories) was applied to surgical sites to minimize postoperative pain and distress. All mice were killed between 11 A.M. and 12 P.M. and all recordings performed between 2 P.M. and 7 P.M. time. All procedures were approved by the Animal Care and Use Committee of the University of Virginia.

Brain slice preparation. All chemicals were purchased from Sigma, unless noted. Brain slices were prepared as described previously (Nunemaker et al., 2002, 2003; Chu and Moenter, 2005). All solutions were bubbled with $95 \% \mathrm{O}_{2}$ and $5 \% \mathrm{CO}_{2}$ to maintain $\mathrm{pH}$ and oxygenation for at least $15 \mathrm{~min}$ before use and throughout experiments. In brief, brains were quickly removed and immersed immediately for 30-60 s in ice-cold sucrose buffer containing the following (in $\mathrm{mM}$ ): 250 sucrose, $3.5 \mathrm{KCl}, 26$ $\mathrm{NaHCO}_{3}, 10$ glucose, $1.25 \mathrm{Na}_{2} \mathrm{HPO} 4,1.2 \mathrm{MgSO}_{4}$, and $3.8 \mathrm{MgCl}_{2}$. Sagittal brain slices $(300 \mu \mathrm{M})$ through the preoptic area (POA) and hypothalamus were cut using a Vibratome 1000 or Vibratome 3000 (Technical Products International). Slices were immediately transferred into a holding chamber and incubated at $31-33^{\circ} \mathrm{C}$ for a $30 \mathrm{~min}$ recovery period in a mixture of $50 \%$ sucrose saline and $50 \%$ artificial CSF (ACSF) containing the following (in $\mathrm{mM}$ ): $135 \mathrm{NaCl}, 3.5 \mathrm{KCl}, 26 \mathrm{NaHCO}_{3}, 1.25 \mathrm{Na}_{2} \mathrm{HPO}_{4}$, $2.5 \mathrm{CaCl}_{2}, 1.2 \mathrm{MgSO}_{4}, 10$ D-glucose, $\mathrm{pH}$ 7.4. Slices were then transferred to $100 \%$ ACSF and maintained at room temperature $\left(\sim 21-23^{\circ} \mathrm{C}\right)$ until study (30 min to $8 \mathrm{~h}$ ).

Data acquisition slices. Data acquisition slices were transferred to a recording chamber mounted on the stage of an upright microscope (Olympus BX50WI; Opelco) and stabilized in the chamber at least $5 \mathrm{~min}$ before recording. The chamber was continuously perfused with ACSF at a rate of $4-5 \mathrm{ml} / \mathrm{min}$ at $32^{\circ} \mathrm{C}$. Pipettes $(3-4 \mathrm{M} \Omega$ ) were pulled from borosilicate glass capillaries (1.65 $\mathrm{mm}$ outer diameter; $1.12 \mathrm{~mm}$ inner diameter; World Precision Instruments) using a Flaming/Brown P-97 (Sutter Instrument). GnRH-GFP neurons from POA and ventral hypothalamus were identified by brief illumination at $470 \mathrm{~nm}$. Data were acquired using one headstage of an EPC-10 dual amplifier (HEKA) controlled by PatchMaster (HEKA). Signals were low-pass filtered at $10 \mathrm{kHz}$. During whole-cell recordings, input resistance $\left(R_{\text {in }}\right)$, series resistance $\left(R_{\mathrm{s}}\right)$, and membrane capacitance $\left(C_{\mathrm{m}}\right)$ were continually measured. Only recordings with stable $R_{\text {in }}>500 \mathrm{M} \Omega$ and $R_{\mathrm{s}}<20 \mathrm{M} \Omega$ and stable $C_{\mathrm{m}}$ were used for analysis. Data were further examined to make sure changes in $R_{\text {in }}$ or $R_{\mathrm{s}}$ within acceptable limits did not influence results. Calculated liquid junction potential error, estimated to be $-13 \mathrm{mV}$, was not corrected (Barry, 1994).

Estradiol $17 \beta(\mathrm{E})$, the main circulating estrogen, was used in all exper- iments. To examine the effects of $\mathrm{E}$, baseline values for a parameter were first established, then estradiol (final concentration $10 \mathrm{pm}-100 \mathrm{nM}$ ), vehicle $(0.01 \%$ ethanol), or other treatment to be followed by estradiol was added to the bath; recording continued and measurements of estradiol effects began after a 5 min wash-in and were completed within 10-15 min of estradiol treatment initiation. In initial experiments, fast synaptic transmission to $\mathrm{GnRH}$ neurons was blocked by antagonists to ionotropic transmitter receptors [GABA $20 \mu \mathrm{m}$ bicuculline methiodide; AMPA 20 $\mu \mathrm{M}$ 6-cyano-7-nitroquinoxaline-2,3-dione (CNQX); NMDA $20 \mu \mathrm{M} \mathrm{D}$ ()2-amino-5-phosphonovaleric acid (APV)]. Some studies omitted these blockers, and their presence or absence is specified in the Results section for each experiment.

Current-clamp recordings. Whole-cell current-clamp recordings were made using bridge balance and capacitance compensation. Pipettes were filled with a solution containing (in $\mathrm{mM}$ ) the following: $120 \mathrm{~K}$ gluconate, $20 \mathrm{KCl}, 10 \mathrm{HEPES}, 5$ EGTA, 4.0 MgATP, 0.4 NaGTP, $1.0 \mathrm{CaCl}_{2}$, pH 7.3, $290 \mathrm{mOsm}$. There was no difference in input resistance (973 $\pm 104 \mathrm{vs}$ $994 \pm 79 \mathrm{M} \Omega$ ) or resting membrane potential $(-63.4 \pm 0.5 \mathrm{vs}-63.9 \pm$ 1.4) among cells during the control period even when different responses to estradiol based on dose were subsequently observed. All cells had an initial membrane potential negative to $-55 \mathrm{mV}$ without current injection and action potential amplitude of $>90 \mathrm{mV}$. DC injection $(< \pm 10$ $\mathrm{pA}$ ) was used to normalize membrane potential to facilitate comparison. Membrane properties were examined as follows. In some cells, action potential firing rate was monitored; changes in firing rate of at least $20 \%$ were used to classify cells as responding to treatment. Tetrodotoxin (TTX; $0.5 \mu \mathrm{M}$; Calbiochem) was added to some recordings to observe underlying changes in membrane potential. To study specific membrane properties, action potentials were elicited in some cells with shortduration ( $3 \mathrm{~ms}$ ) current pulses $(300 \mathrm{pA})$ as in Chu and Moenter, 2006. When multiple pulses were given, they were separated by $50 \mathrm{~ms}(20 \mathrm{~Hz})$. Each protocol was run 10 times at $2 \mathrm{~s}$ intervals, and all 10 traces were averaged for analysis. Amplitude of the afterhyperpolarization (AHP) and slow afterdepolarization (sADP) that followed the action potential was measured from the prespike baseline. To examine effects of $\mathrm{E}$ on excitability, longer duration current injections (600 ms $0-50 \mathrm{pA}$ ) were given. Latency was defined as the time from start of the current injection (25-30 pA) to the peak of first action potential. The amount of current needed to initiate firing, spike threshold (defined as the point where the derivative of the trace exceeded $1 \mathrm{~V} / \mathrm{s}$ ), number of spikes, and spike amplitude (measured from spike threshold) were determined before and after estradiol treatment. The input resistance of GnRH neurons was determined from the steady-state voltage response to a depolarizing pulse (10-15 pA producing $\sim 10 \mathrm{mV}$ change in membrane potential). Membrane potential changes in response to current injection were determined during the plateau after current injection began and before action potential firing was initiated.

Voltage-clamp recordings. Whole-cell voltage-clamp was used to study currents underlying the AHP and sADP using the same pipette solution as current-clamp studies. Cells were held at $-60 \mathrm{mV}$. Current response to single, double, or quadruple $2 \mathrm{~ms}$ square voltage pulses, or simulated action potentials, separated by $50 \mathrm{~ms}$, was evaluated. Stimuli were repeated 50 times and traces averaged for analysis. Amplitude of the outward current $\left(I_{\mathrm{AHP}}\right)$ and inward current $\left(I_{\mathrm{ADP}}\right)$ was measured from the precommand baseline. For whole-cell recording of $\mathrm{GABA}_{\mathrm{A}}$ receptormediated postsynaptic currents (PSCs), cells were held at $-60 \mathrm{mV}$, and pipettes were filled with high-chloride solution containing the following (in mM): $140 \mathrm{KCl}, 10$ HEPES, 5 EGTA, $4.0 \mathrm{MgATP}, 0.4 \mathrm{NaGTP}, 1.0$ $\mathrm{CaCl}_{2}$, pH 7.3, 290 mOsm.

Cell culture and Western blot. To confirm the efficacy of the $G_{1}$ agonist, its ability to stimulate mitogen-activated protein kinase (MAPK) (ERK1/2) activity was measured. Ishikawa endometrial carcinoma cells, which respond to $G_{1}$, were plated in $35 \mathrm{~mm}$ wells $\left(10^{6}\right.$ cells per well) as described previously (Bryant et al., 2005; Vivacqua et al., 2006). After serum starvation overnight, cells were treated in serum-free, phenol-redfree Dulbecco's Essential Medium containing either ethanol vehicle $(0.01 \%), 10 \mathrm{~nm}$ E2, and either 100 or $500 \mathrm{~nm} \mathrm{G}_{1}$ for $15 \mathrm{~min}$. After treatment, cells were collected in SDS-containing gel buffer; $10 \mu \mathrm{g}$ total protein was subjected to electrophoresis, transferred to nitrocellulose mem- 


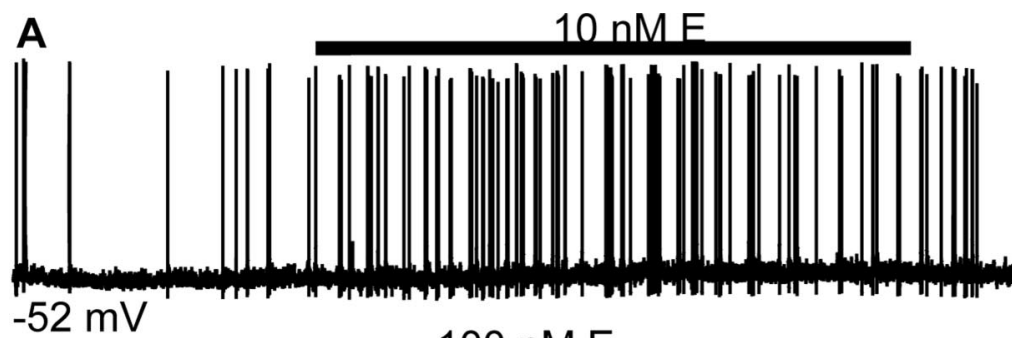

$10 \mathrm{nME}$
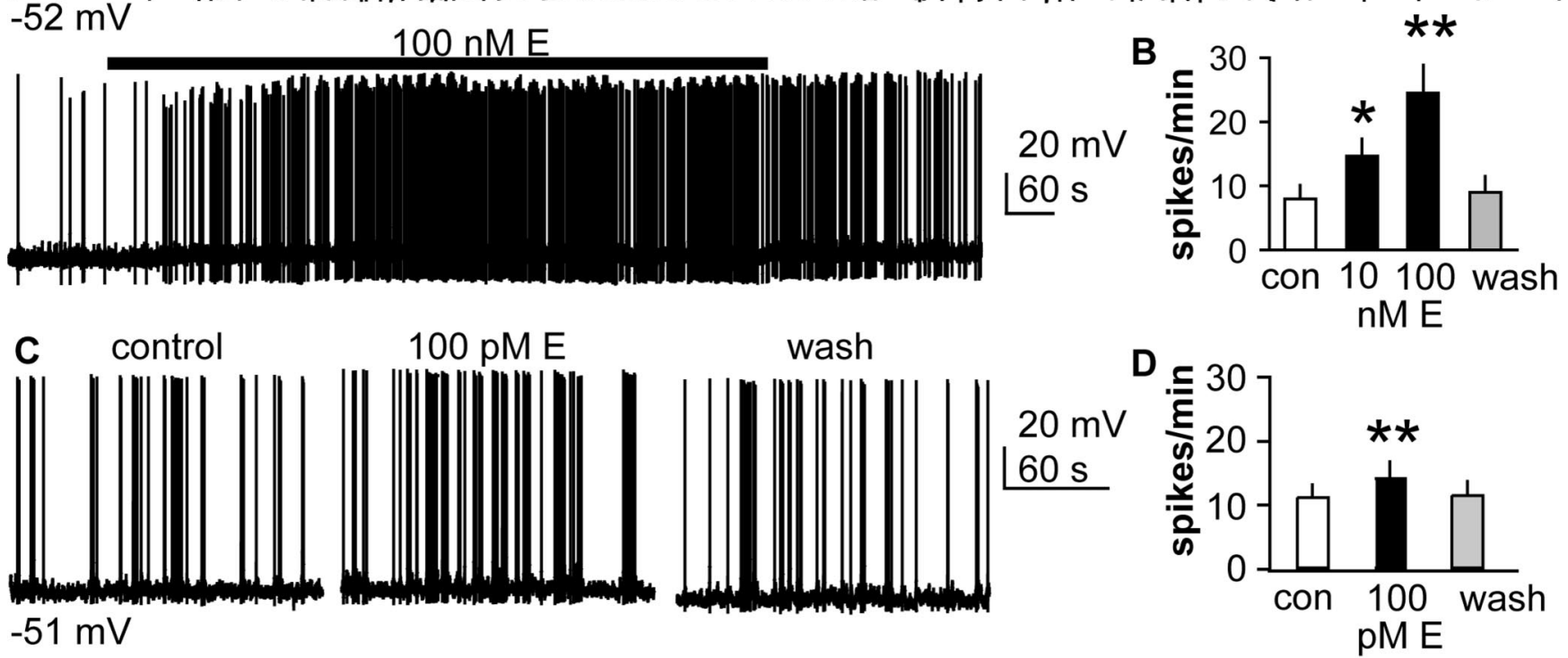

$-51 \mathrm{mV}$

E control

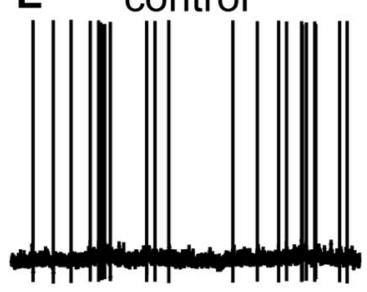

$1 \mathrm{nME}$

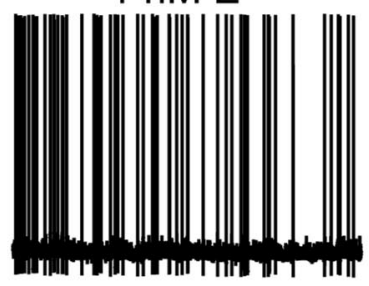

wash

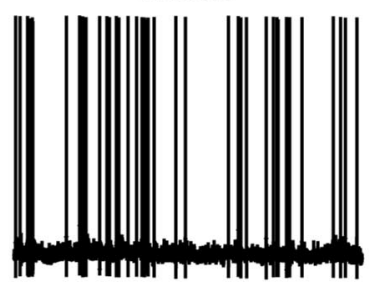

$-53 \mathrm{mV}$
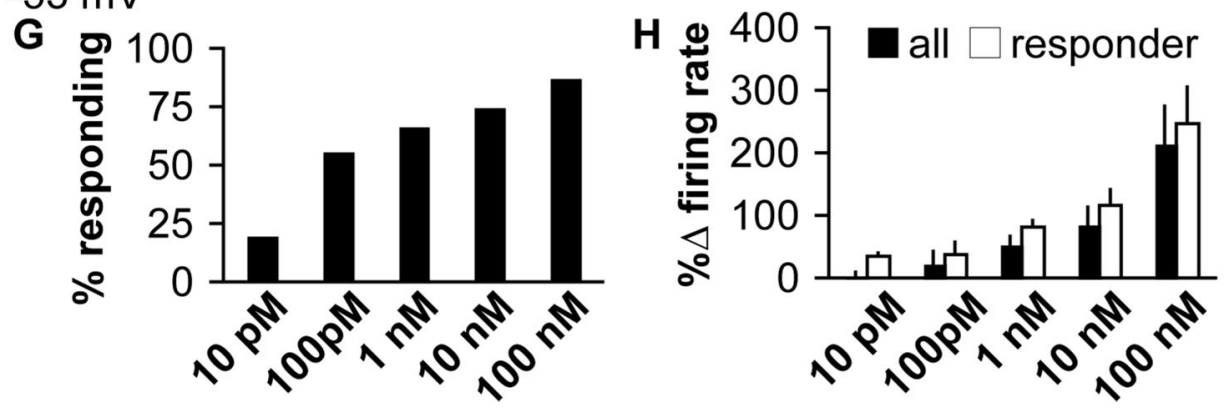

$\mathbf{F}$

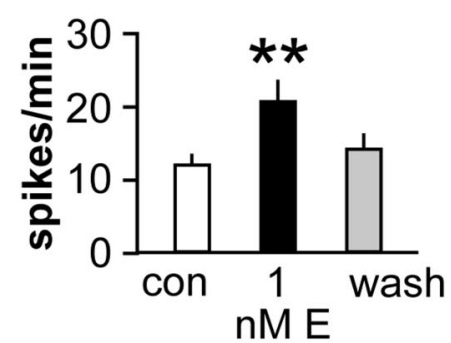

Figure 1. Estradiol (100 pm to $100 \mathrm{~nm}$ ) increases firing rate of GnRH neurons. $A$, Representative continuous current-clamp recording of spontaneous firing in a GnRH neuron showing the excitatory effect of $10 \mathrm{~nm}$ estradiol and wash-out; second line is the same neuron $10 \mathrm{~min}$ later at start of trace showing response to $100 \mathrm{~nm}$ estradiol. $\boldsymbol{B}$, Summary of spikes per minute in different conditions ( 10 $\mathrm{nм}, n=20 ; 100 \mathrm{~nm}, n=8)$. C, Representative response to $100 \mathrm{pm}$ estradiol. $\boldsymbol{D}$, Mean \pm SEM response to $100 \mathrm{pm}$ estradiol $(n=16)$. $\boldsymbol{E}$, Representative response to $1 \mathrm{~nm}$ estradiol. $\boldsymbol{F}$, Mean \pm SEM response to $1 \mathrm{~nm}$ estradiol ( $n=18)$. G, Summary of percentage of cells responding by dose. $\boldsymbol{H}$, Percentage change in firing rate when all cells are quantified (black bars) or just responding cells are quantified (white bars). ${ }^{*} p<0.01,{ }^{* *} p<0.001$.

branes, and assayed for phosphorylated (activated) and total ERK1/2 with specific antibodies (Cell Signaling Technology) as described previously (Song et al., 2002; Bryant et al., 2005).

Drug treatments. The following treatments were bath applied. The G-protein-coupled estradiol receptor GPR30 (Revankar et al., 2005) was activated with the $G_{1}$ agonist (100-500 $\left.\mu \mathrm{M}\right)$ (Bologa et al., 2006). The pure nuclear estrogen receptor antagonist ICI182780 $(1 \mu \mathrm{M})$ was used to block effects through ER $\alpha$ and ER $\beta$. The $\mathrm{ER} \alpha$-specific agonist propylpyrazoletriol (PPT) and the ER $\beta$-specific agonist 2,3-bis(4hydroxyphenyl)-propionitrile (DPN) were both used at $10 \mathrm{~nm}$ (Har- rington et al., 2003; Sun et al., 2003). Small conductance calciumactivated potassium currents $\left(I_{\mathrm{KCa}}\right)$ were blocked with $200 \mathrm{~nm}$ apamin; large conductance $I_{\mathrm{KCa}}$ were blocked with $100 \mathrm{~nm}$ iberiotoxin (IbTx). Protein kinase A (PKA) was blocked with 100 nм KT5720.

Statistical analyses. Statistical analyses were performed using Instat or Prism (Graphpad Software). Responding cells were defined as those with a $>20 \%$ change in firing rate. Values for electrophysiological data are expressed as mean \pm SEM. Each cell served as its own control. All statistical comparisons were made using paired two-tailed Student's $t$ test. Significance was set at $p<0.05$; all nonsignificant $p$ values were $>0.1$, unless specified. 


\section{Results}

High physiological (100 pM) through nanomolar concentrations of estradiol increase GnRH neuron activity To test if estradiol acutely alters GnRH neuron activity, currentclamp recordings were made of $\mathrm{GnRH}$ neurons before, during, and after treatment with estradiol $(10-100 \mathrm{nM})$. Fast synaptic transmission via ionotropic GABA and glutamate receptors was blocked in all recordings, unless indicated. After establishing baseline values, estradiol was added to the bath; effects were assessed after a $5 \mathrm{~min}$ wash-in, and measurements were complete within $10-15$ min of treatment initiation. Estradiol $(10-100 \mathrm{nM})$ rapidly increased the firing rate of $70 \%$ of recorded $\mathrm{GnRH}$ neurons (10 nM, 14 of 20 cells; $100 \mathrm{nM}, 7$ of 8 cells) by an average of twofold to threefold in a dose-dependent manner (Fig. $1 A, B)(10$ nM estradiol, $p<0.001, n=20 ; 100 \mathrm{~nm}$ estradiol, $p<0.001, n=$ $8)$. This effect was reversible, with action potential firing returning to pretreatment levels within 15-20 min (Fig. 1A,B). Vehicle $(0.01 \%$ ethanol) had no effect (data not shown).

Although estradiol doses of 10-100 nM are commonly used, particularly in brain slice preparations in which higher concentrations are needed for slice penetration, these levels are higher than those achieved during the preovulatory peak of estradiol in vivo. We thus examined the response to $100 \mathrm{pM}$, which is in the high end of the physiological range, and $1 \mathrm{~nm}$ estradiol; these concentrations also increased firing in GnRH neurons (Fig. $1 C-F)(100 \mathrm{pM}, p<0.01, n=16 ; 1 \mathrm{nM}, p<0.001, n=18)$. Membrane depolarization preceding increased firing was observed at the $100 \mathrm{~nm}$ dose in some cells ( 5 of 8 cells; mean depolarization, $7.2 \pm 1.2 \mathrm{mV}$ ); at other doses, changes in this parameter were often within the range of noise of the baseline (data not shown). Increasing concentrations of estradiol increased both the percentage of cells responding to treatment and the change in firing rate (Fig. 1G,H). Changes in firing rate and membrane polarization were observable within $5 \mathrm{~min}$ of the addition of estradiol to the bath, strongly suggesting nongenomic mechanisms were engaged.

We next identified the estrogen receptor subtype mediating these effects. The pure classical estrogen receptor antagonist ICI 182780 blocks signaling through both known intracellular forms of the estrogen receptor, ER $\alpha$ and ER $\beta$. ICI182780 had no effect on its own (Fig. $2 A)(n=8)$ but completely abolished the ability of nanomolar estradiol to increase firing of $\mathrm{GnRH}$ neurons (Fig. $2 A, F)(n=8)$. The ER $\beta$ agonist DPN $(10 \mathrm{~nm})$ increased GnRH neuron firing in a manner similar to the native ligand in a majority of cells (Fig. $2 B, F)(n=12, p<0.01)$. In contrast, the ER $\alpha$ agonist PPT ( $10 \mathrm{~nm}$ ) had no effect on GnRH neuron activity (Fig. $2 C, F)(n=6)$. Consistent with the blockade of estradiol action by ICI182780, $\mathrm{G}_{1}$, an agonist of GPR30, a putative estrogen receptor, also had no effect on GnRH neuron firing (Fig. $2 D, F)(n=6) . \mathrm{G}_{1}$ was shown to be active in a Western blot of Ishikawa human endometrial carcinoma cells, demonstrating phosphorylation of extracellularly regulated kinase (ERK1/2) (Fig. 2E). Furthermore, as ICI182780 had no effect on its own and has been shown to activate $G_{1}$ (Prossnitz et al., 2008), this further indicates that a classical estrogen receptor mediates the effects. Together, these data suggest nanomolar levels of estradiol activate GnRH neuron firing via $\mathrm{ER} \beta$.

Nanomolar estradiol increases excitability and alters the AHP and SADP and their underlying currents

To begin to understand the mechanism by which acutely applied estradiol increases $\mathrm{GnRH}$ neuron firing, we examined excitability (Fig. 3). DC current $(< \pm 10 \mathrm{pA})$ was injected in some cells to
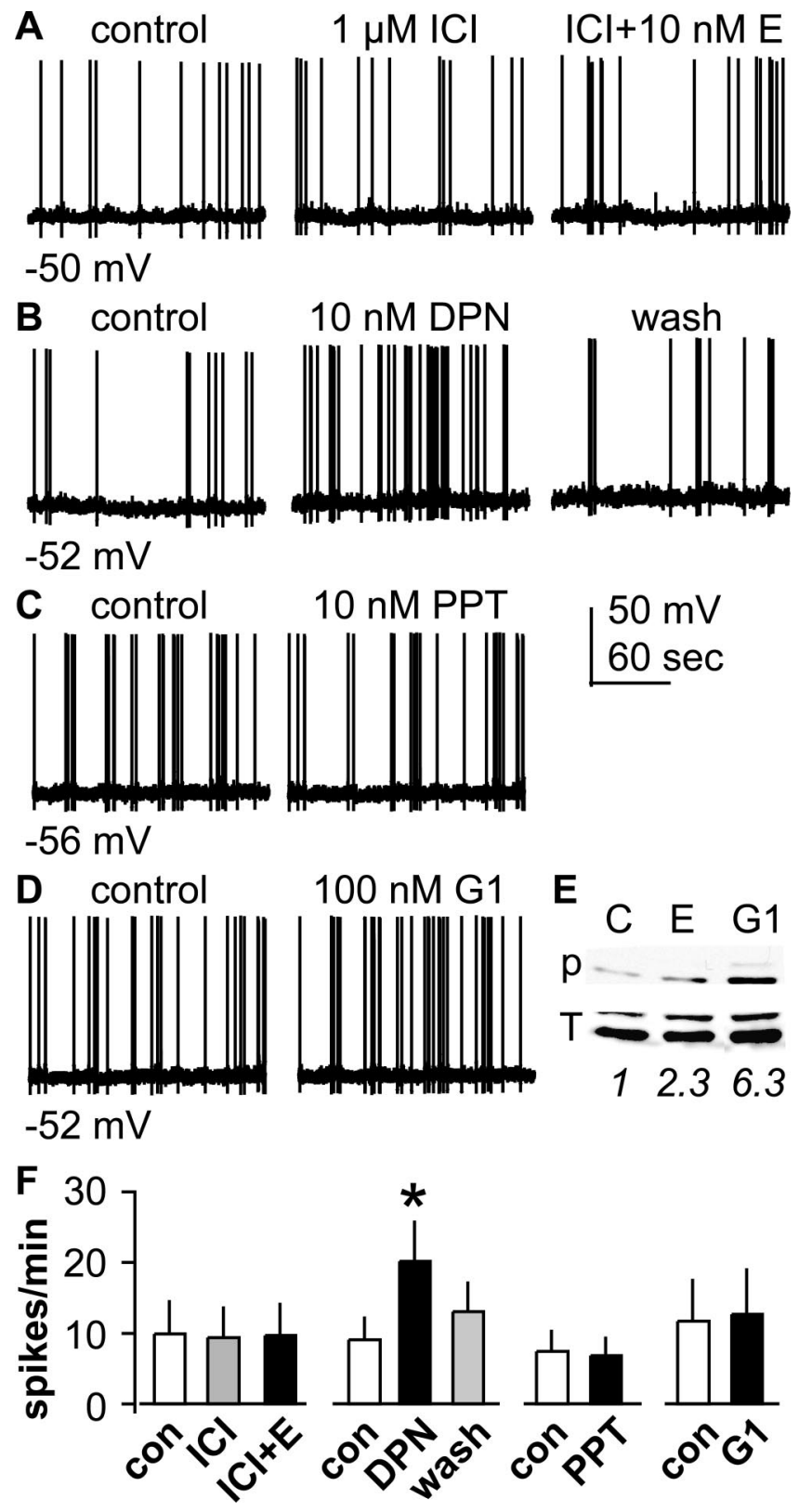

Figure 2. Classical $E R \beta$ mediates the acute effects of nanomolar estradiol on GnRH neurons. $A-D$, Representative 3 min segments of continuous current-clamp recordings before and after treatment, followed by wash or subsequent treatment. $A$, ICI182780 has no effect on its own but blocks the stimulatory effect of $10 \mathrm{~nm}$ estradiol. $\boldsymbol{B}$, The ER $\beta$ agonist DPN reversibly increases $G n R H$ neuron firing. $C$, The $E R \alpha$ agonist DPN has no effect. $D$, The GPR30 agonist $G_{1}$ has no effect. $\boldsymbol{E}$, Western blot of Ishikawa cells showing phosphorylation of ERK relative to control (C) induced by $10 \mathrm{~nm}$ estradiol (E) or $100 \mathrm{~nm} \mathrm{G}_{1}$ (p) and total ERK 1/2 (T). Numbers in italics below lanes indicate fold induction of phospho ERK. $F$, Summary of spikes per minute (ICI, $n=8 ; \mathrm{DPN}, n=$ $\left.12 ; \mathrm{PPT}, n=6 ; G_{1}, n=6\right)$. ${ }^{*} p<0.01$.

bring the membrane potential to approximately $-60 \mathrm{mV}$, then depolarizing current injection steps were given. Estradiol (10 nM) increased the excitability of $\mathrm{GnRH}$ neurons manifested as a shorter latency to action potential initiation (control, $294 \pm 35$ ms vs estradiol, $162 \pm 26 \mathrm{~ms}, p<0.05$ ), hyperpolarized threshold potential for action potential initiation (control, $-33.4 \pm 1.6 \mathrm{mV}$ vs estradiol, $-37 \pm 1.7 \mathrm{mV}, p<0.05$ ), increased input resistance (control, $973 \pm 104 \mathrm{M} \Omega$ vs estradiol, $1050 \pm 106 \mathrm{M} \Omega, p<0.05$ ), increased membrane depolarization in response to current injection and greater number of spikes fired at each current injection 

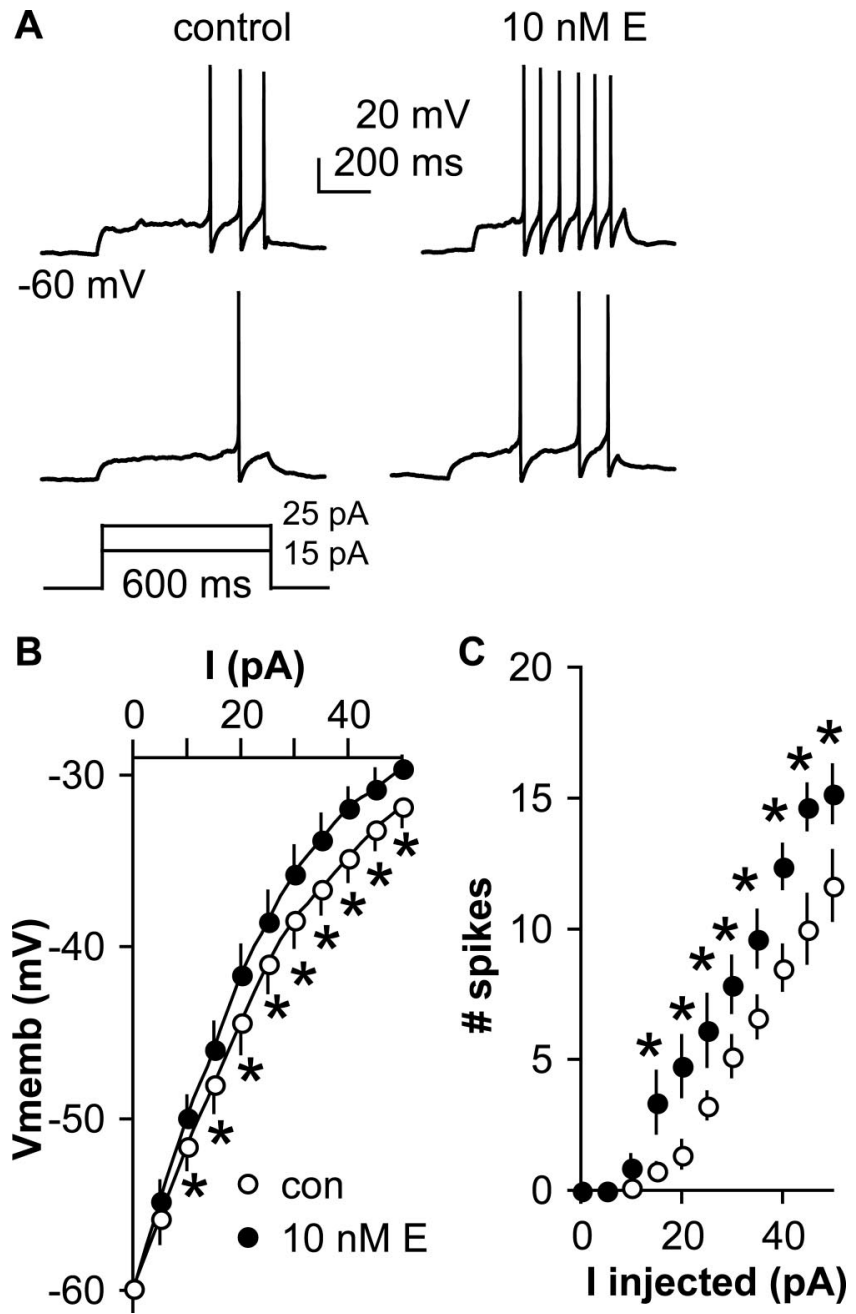

Figure 3. Nanomolar estradiol increases GnRH neuron excitability. $A$, Bottom, Current injection protocol; top, resulting membrane response before (left) and after (right) bath application of $10 \mathrm{~nm}$ estradiol. Just two steps are shown for clarity. $\boldsymbol{B}$, Mean \pm SEM membrane potential change in response to current injection. $C$, Mean \pm SEM number of spike elicited during the control and $10 \mathrm{~nm}$ estradiol treatment periods for each current injection. ${ }^{*} p<0.05$.

but did not change spike amplitude (control, $79 \pm 3 \mathrm{mV}$ vs estradiol, $81 \pm 2 \mathrm{mV}$ ).

To more closely examine action potential waveform, brief current injections ( $300 \mathrm{pA}, 3 \mathrm{~ms}$ ) were applied to induce single action potentials or pairs separated by $50 \mathrm{~ms}$ (Chu and Moenter, 2006). Estradiol (10 nM) markedly reduced the amplitude of the AHP (Fig. $4 A, B)(n=14, p<0.01)$. The sADP characteristic of GnRH neurons was also enhanced (Fig. $4 A)(n=14, p<0.01)$. This latter finding may be a consequence of the former as the absolute amplitude from the peak of the AHP to peak of the ADP did not change (control, $10.1 \pm 0.5 \mathrm{mV}$; estradiol, $10.0 \pm 0.5$ $\mathrm{mV}$ ), suggesting that a reduction in the outward current underlying the AHP may have caused a depolarizing shift in the entire after-spike waveform. Blockade of both large- and smallconductance $I_{\mathrm{KCa}}$ with iberiotoxin and apamin reduced the AHP and enhanced the SADP to similar extents as nanomolar estradiol and occluded further response to estradiol, consistent with this postulate (Fig. $4 E, F)(n=9, p<0.01)$. ICI182780 blocked the effects of estradiol (Fig. $4 C, E, F)(n=6)$, whereas $\mathrm{G}_{1}$ and vehicle were without effect (Fig. $4 D-F)(n=6$ and 8, respectively).

To begin to examine the mechanisms underlying the changes in membrane properties, we performed whole-cell voltage-clamp

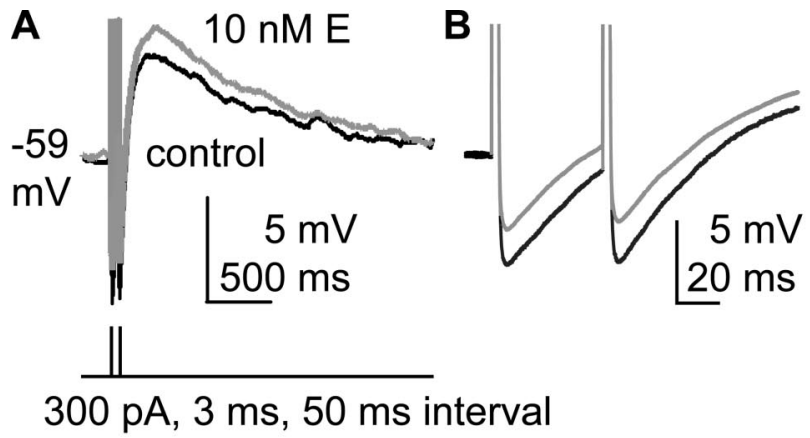

C control $1 \mu \mathrm{M} \mathrm{ICl} \quad \mathrm{ICl}+10 \mathrm{nME}$
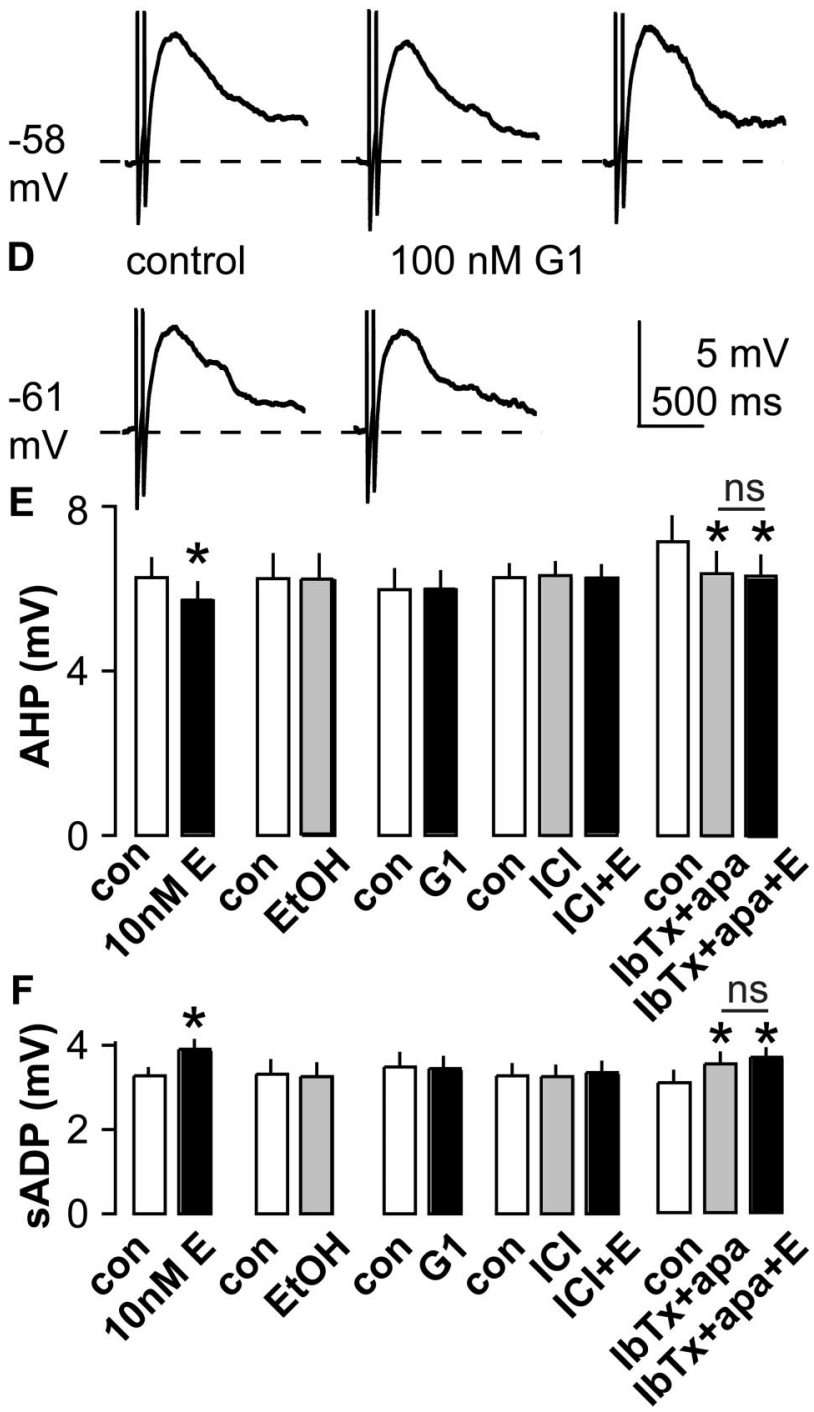

Figure 4. Nanomolar estradiol alters AHP and SADP. All action potential spikes are truncated in this figure. $A$, Current-clamp trace showing action potentials elicited by brief current injections (bottom). Black line shows control and gray line after $10 \mathrm{~nm}$ estradiol. $\boldsymbol{B}$, Expanded time scale to better illustrate AHP. C, ICI182780 blocks the effects of estradiol on the AHP and sADP. $D, G$, has no effect on ADP or AHP. $E, F$, Summary of estradiol effects on SADP and AHP, respectively $\left[10 \mathrm{~nm} \mathrm{E}, n=14\right.$; ethanol (EtOH), $n=8 ; \mathrm{G}_{1}, n=6 ; \mid \mathrm{Cl}, n=6$; IbTx plus apa, $\left.n=9\right]$ ]. ${ }^{*} p<$ $0.01 ;$ ns, nonsignificant.

studies. From a holding potential of $-60 \mathrm{mV}$, cells were depolarized to $+20 \mathrm{mV}$ for $2 \mathrm{~ms}$, to mimic the depolarization of an action potential. After the current artifacts of the voltage step, a fast outward current was observed, followed by a slower inward cur- 

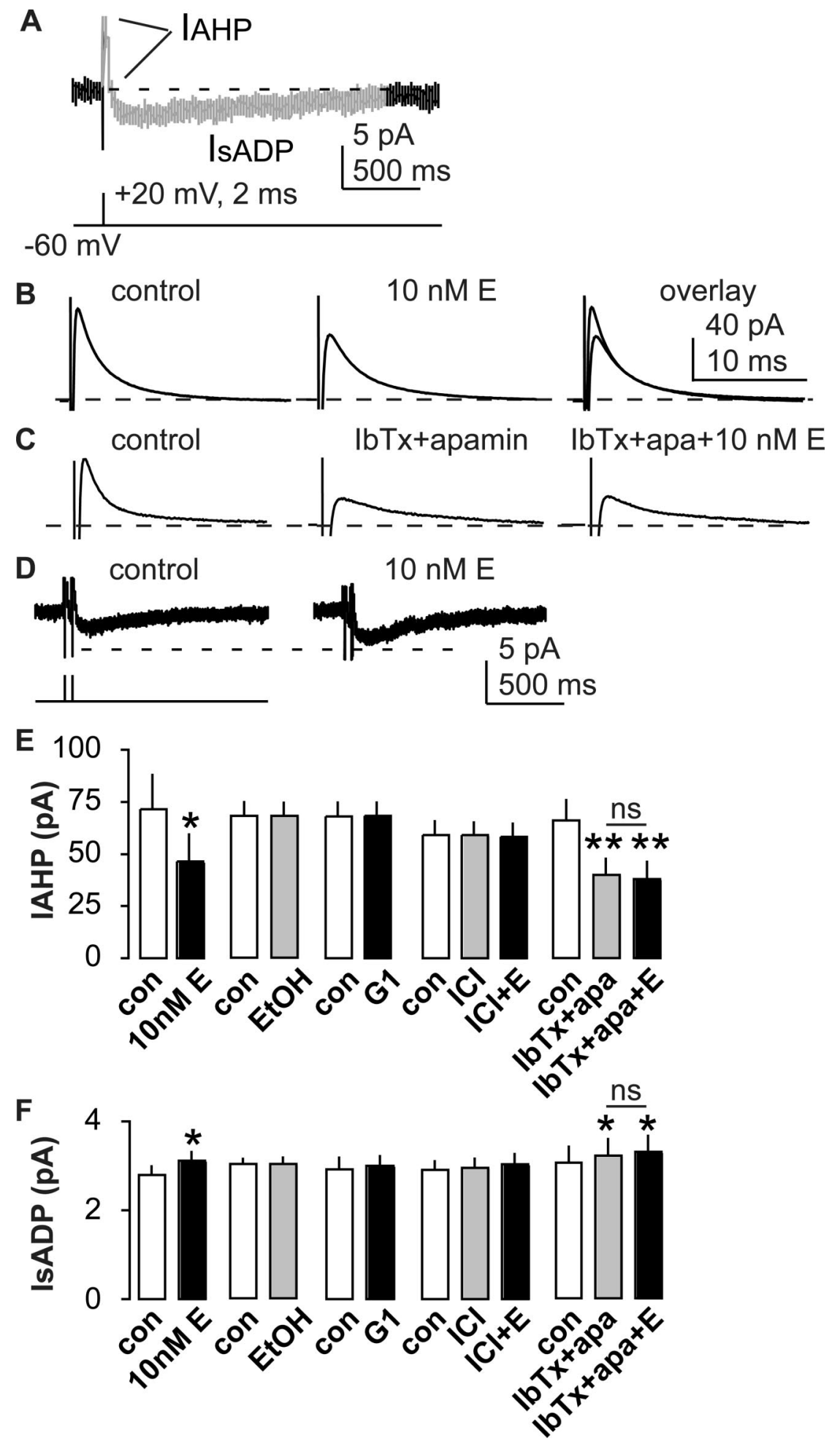

Figure 5. Nanomolar estradiol acutely alters the currents underlying the AHP and SADP. A, Voltage-clamp recording of total membrane current (top) in response to spike depolarization (bottom), showing $I_{\text {AHP }}$ (above dashed line) and $I_{\text {ADP }}$ (below dashed line) in gray. $\boldsymbol{B}$, Estradiol decreases $I_{A H P}$ amplitude. $C$, IbTx and apamin (apa) reduce the amplitude of the $I_{\text {AHP }}$ and occlude the response to estradiol. $\boldsymbol{D}$, Estradiol increases $I_{A D P} . E, F$, Summary of estradiol effects on $I_{A D P}$ and $I_{A H P}$, respectively $[10 \mathrm{nM} E, n=11$; ethanol (EtOH), $n=7 ; \mathrm{G}_{1}, n=7 ; \mathrm{ICl}, n=8 ; \mathrm{IbTx}$ plus apa, $\left.n=7\right] .{ }^{*} p<0.05$ and ${ }^{* *} p<0.01 ; \mathrm{ns}$, nonsignificant.

rent (Fig. 5A). The former is the current underlying the AHP $\left(I_{\mathrm{AHP}}\right)$ and the latter that underlying the sADP $\left(I_{\mathrm{ADP}}\right)$. Estradiol (10 nM) acutely reduced the $I_{\mathrm{AHP}}$ (Fig. $\left.5 B, E\right)(n=11, p<0.01)$ and enhanced the $I_{\mathrm{ADP}}$ (Fig. $\left.5 D, F\right)(n=11, p<0.05)$. As with membrane properties, these changes were blocked by ICI182780, with $\mathrm{G}_{1}$ and the vehicle having no effect (Fig. $5 E, F$ ).

In previous work, the $I_{\mathrm{ADP}}$ was shown to be conducted via a TTX-sensitive sodium channel and modulated by in vivo treatment with estradiol (Chu and Moenter, 2006). We thus focused on the ionic basis of the $I_{\mathrm{AHP}}$. Further analysis of these published data revealed that in vivo treatment with estradiol reduced the $I_{\mathrm{AHP}}(\mathrm{OVX}, 63.9 \pm 9.4 \mathrm{pA}$ vs OVX plus E, $40.1 \pm 6.6 \mathrm{pA}, n=14, p<0.05$ ) to a similar extent as observed for acute estradiol in the present study (Fig. 5). In the present study, pharmacological blockade of $I_{\mathrm{KCa}}$ with iberiotoxin and apamin markedly reduced the amplitude of the $I_{\mathrm{AHP}}$ (Fig. $5 C, E)(n=7, p<0.01)$. Moreover, blockade of $I_{\mathrm{KCa}}$ occluded further response to estradiol ( $p>0.3$ vs iberiotoxin/apamin alone).

To begin to examine the signaling mechanism engaged by estradiol, we examined the ability of blocking signaling via PKA on the response to estradiol. PKA was chosen because it is one upstream activator of the cAMP response element-binding protein (CREB), which has been implicated in the rapid actions of estradiol in GnRH neurons by in vivo studies (Abrahám et al., 2003). The cell permeant PKA inhibitor KT5720 eliminated the excitatory effects of $1 \mathrm{~nm}$ estradiol on spontaneous firing rate (Fig. 6). These data suggest that estradiol activates PKA to modulate $I_{\mathrm{AHP}}$ by reducing conductance through calcium-activated potassium channels, consistent with the increase in input resistance observed with acute estradiol treatment (Fig. 3C).

\section{Low physiological concentrations of estradiol (10 pM) do not affect GnRH neuron activity or intrinsic properties when fast synaptic transmission is blocked}

Estradiol has biphasic and dosedependent effects on GnRH neuron activity and release. Lower levels of estradiol typically provide homeostatic (negative) feedback, whereas during the female reproductive cycle, exposure to the sustained high level of estradiol in the circulation at the end of the follicular phase elicits a neurobiological switch to positive feedback action, inducing a massive surge in GnRH neuron activity that serves as a central initiator of the ovulatory process. Because of the dose dependence, we examined the effects of low levels of estradiol to determine if the response of GnRH neurons was similar. Estradiol ( $10 \mathrm{pM}, n=10)$ had no effect on GnRH neuron firing in the same recording conditions in which all of the above recordings were made, with fast synaptic transmission via ionotropic GABA and glutamate receptors blocked (Fig. $7 A, B$ ). 
A control

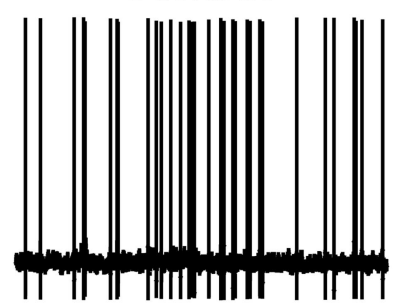

$-50 \mathrm{mV}$
100 nM KT5720

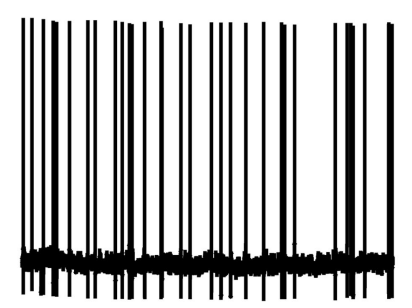

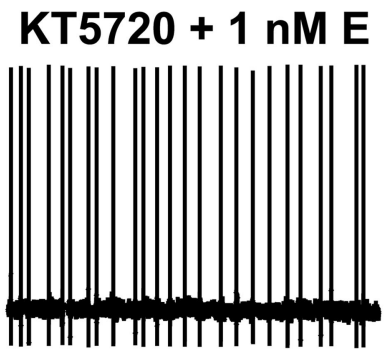

$50 \mathrm{mV}$ $60 \mathrm{~s}$

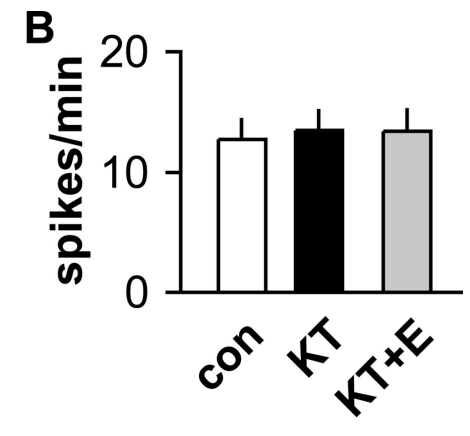

Figure 6. The excitatory response to $1 \mathrm{~nm}$ estradiol is eliminated by blocking PKA activity. $\boldsymbol{A}$, Representative recording during control, $100 \mathrm{~nm}$ KT5720 and 100 nм KT5720 plus $1 \mathrm{~nm}$ estradiol. $\boldsymbol{B}$, Mean \pm SEM spikes per minute $(n=14)$.

Low physiological (10 pM) estradiol decreases GnRH neuron activity when synaptic transmission within the brain slice is left intact

Much of the feedback action of estradiol is thought to require $\mathrm{ER} \alpha$ (Wintermantel et al., 2006). Because the expression of ER $\alpha$ by GnRH neurons is controversial and because feedback actions of estradiol have been shown to be at least in part via presynaptic mechanisms (Couse and Korach, 1999; Wintermantel et al., 2006; Christian and Moenter, 2007; Christian and Moenter, 2008b), we examined the effect of both $10 \mathrm{~nm}$ and $10 \mathrm{pm}$ estradiol on $\mathrm{GnRH}$ neurons in brain slices in which fast synaptic transmission was operable. Importantly, there was no change in action potential properties of $\mathrm{GnRH}$ neurons between slices that were treated with APV, CNQX, and bicuculline and those that were not, indicating no confounding effects of potential nonspecific actions (data not shown, although compare Figs. $3 A$ and $8 A$ ). The $10 \mathrm{~nm}$ dose of estradiol had a stimulatory effect on approximately half $(9$ of 17) of GnRH neurons studied (for all cells studied: control, $12.4 \pm 3.0$; estradiol, $15.7 \pm 3.5$ spikes $/ \mathrm{min}, n=17, p<0.05$; for responding cells: control, $10.0 \pm 2.7$; estradiol, $15.9 \pm 3.7$ spikes/ min, $n=9, p<0.01)$. In marked contrast, both to the lack of effect of $10 \mathrm{pm}$ estradiol in blocked slices and the stimulatory effect of nanomolar estradiol in blocked and unblocked slices, 10 pM estradiol inhibited GnRH neuron firing in 9 of 16 cells (Fig. $7 C, G)(n=16, p<0.01)$. This effect was blocked by ICI182780 (Fig. $7 D)(n=6)$. The ER $\beta$ agonist DPN had no effect on GnRH neuron firing when fast synaptic transmission was not blocked (Fig. 7E). In contrast, the $\mathrm{ER} \alpha$ agonist PPT (10 nM) reversibly inhibited GnRH neuron firing in slices in which fast synaptic transmission was not blocked (Fig. $7 F)(n=6$ of 17 cells tested, $p<0.01$ for $n=6$ responding cells, $p<0.07$ for $n=17$ cells studied). There was no effect of $10 \mathrm{pm}$ estradiol on input resistance (control, $994 \pm 79 \mathrm{M} \Omega$; estradiol, $980 \pm 83 \mathrm{M} \Omega, n=7$ ), sADP amplitude (control, $3.5 \pm 0.2 \mathrm{mV}$ vs estradiol, $3.3 \pm 0.2$ $\mathrm{mV}$ ), AHP amplitude (control, $7.7 \pm 0.6 \mathrm{mV}$ vs estradiol, $7.7 \pm$ $0.6 \mathrm{mV}), I_{\mathrm{ADP}}$ (control, $3.0 \pm 0.2 \mathrm{pA}$ vs estradiol, $3.0 \pm 0.2 \mathrm{pA}$ ), $I_{\mathrm{AHP}}$ (control, $63.6 \pm 12.0 \mathrm{pA}$ vs estradiol, $61.9 \pm 11.2 \mathrm{pA}$, all $n=$ 11-12) or other intrinsic membrane properties examined (Fig. $8 A-C)(n=7)$. Together, these data suggest picomolar estradiol decreases $\mathrm{GnRH}$ neuron activity via a presynaptic mechanism(s).

GABA transmission to GnRH neurons is acutely altered in an estradiol receptor subtype-dependent manner

To begin to explore transsynaptic mechanisms for acute estradiol action, we examined GABA transmission in unblocked slices. GABA was chosen as it is a major mediator of fast syn- aptic transmission on GnRH neurons; although glutamatergic transmission is observed (Suter, 2004; Christian et al., 2009), it is of much lower frequency. Indeed, blockade of $\mathrm{GABA}_{\mathrm{A}}$ receptors with bicuculline eliminates most spontaneous fast synaptic transmission detectable at the cell body (Fig. 9A) (ionotropic glutamate receptors are not blocked in these recordings). Of note, GnRH neurons have been reported to maintain elevated chloride levels in adult animals (DeFazio et al., 2002; Yin et al., 2008), and thus can be depolarized and even excited by GABA, although this remains an area of controversy (Han et al., 2004; Moenter and DeFazio, 2005). The $\mathrm{ER} \alpha$ agonist PPT significantly reduced the frequency of GABA transmission to $\mathrm{GnRH}$ neurons (Fig. 9B,F) $(n=17, p<$ 0.001 ) but had no effect on amplitude (Fig. $9 D, G$ ), consistent with an inhibitory network effect of low-dose estradiol via $\mathrm{ER} \alpha$. In contrast, the ER $\beta$ agonist DPN increased frequency of GABA transmission (Fig. $9 C, F)(n=14, p<0.001)$ as well as amplitude of GABAergic PSCs (Fig. $9 E, G)(p<0.001)$. These data provide proof-of-principle that estradiol can act rapidly via both classical receptor subtypes to change transmission to GnRH neurons in a receptor subtype-dependent manner.

\section{Discussion}

The feedback actions of estradiol to regulate GnRH release are complicated. During the reproductive cycle, low levels of estradiol are typically associated with suppression of $\mathrm{GnRH}$ release via homeostatic negative feedback, whereas sustained exposure to higher levels at the end of the follicular phase triggers one of the rare positive feedback events in physiology, the GnRH surge, which triggers generation of the pituitary signal for ovulation. Although these whole-organism responses have long been recognized, the underlying mechanisms are less understood. There is now appreciation that steroids, including estradiol, can signal through both genomic mechanisms and rapid changes in signaling cascades. We examined the effects of acutely applied estradiol on $\mathrm{GnRH}$ neurons in brain slices. The short latency $(<5 \mathrm{~min})$ of responses strongly argues for a mechanism that does not rely on changes in gene expression via classical or nonclassical mechanisms. The direction of response to acutely applied estradiol varies with dose, and stimulatory versus inhibitory actions appear to involve different receptor subtypes and different neurobiological mechanisms.

High physiological and greater doses of estradiol (100 pM to $100 \mathrm{~nm}$ ) depolarized GnRH neurons, increasing firing activity. Depolarization was observed after blocking fast synaptic transmission and action potential generation, which minimizes neu- 


\section{A APV+CNQX+BIC} control

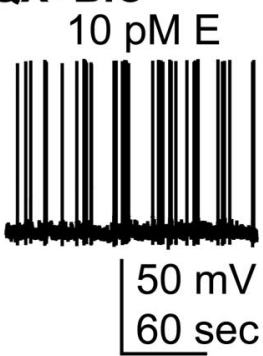

B

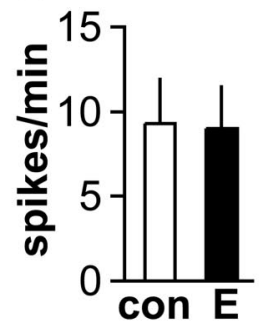

C No APV+CNQX+BIC (C thru G) control

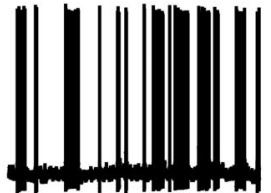
$10 \mathrm{pM} \mathrm{E}$
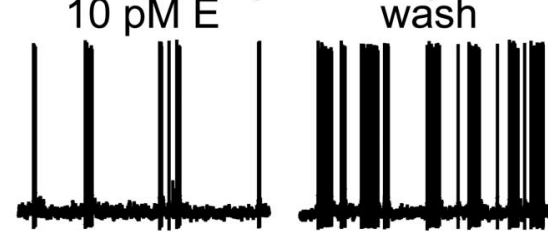

- $49 \mathrm{mV}$

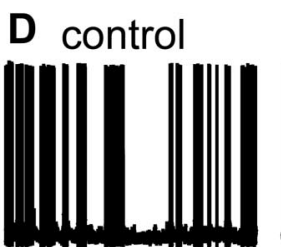

$1 \mu \mathrm{M} \mathrm{ICl}$

$\mathrm{ICl}+10 \mathrm{pM} \mathrm{E}$
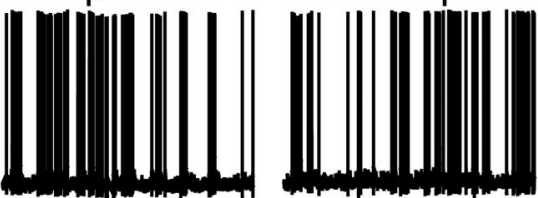

$-47 \mathrm{mV}$

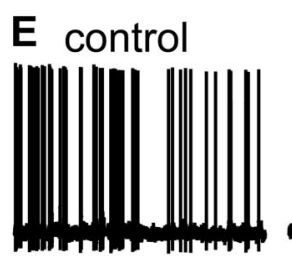

$10 \mathrm{nM}$ DPN

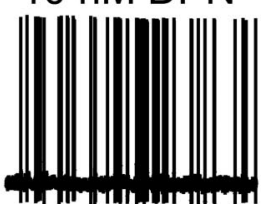

$-50 \mathrm{mV}$

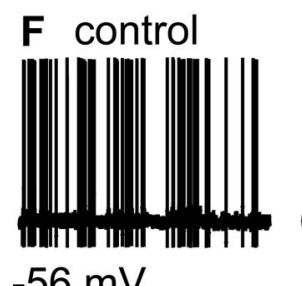

10 nM PPT
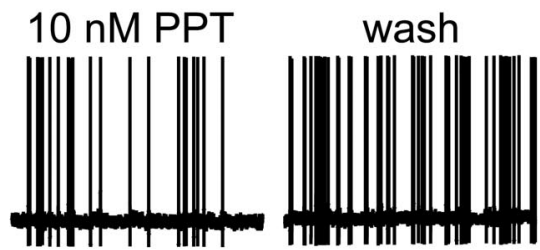

$-56 \mathrm{mV}$
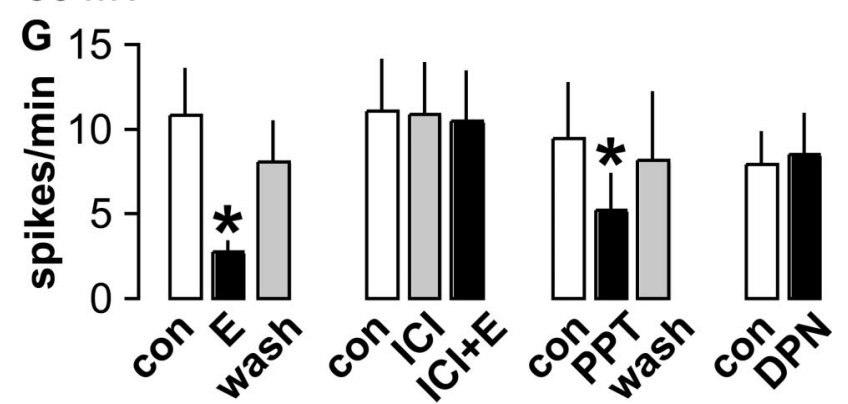

Figure 7. Picomolar concentrations of estradiol inhibit $\mathrm{GnRH}$ neuron firing via the presynaptic network in an ER $\alpha$-dependent manner. $\boldsymbol{A}$, In the presence of blockers of ionotropic GABA and glutamate receptors, representative 3 min segments of continuous current-clamp recording before and during treatment with $10 \mathrm{pm}$ estradiol. $\boldsymbol{B}$, Summary of the effects of picomolar estradiol on firing. $\boldsymbol{C}$, In absence of blockers of ionotropic GABA and glutamate receptors, $10 \mathrm{pm}$ estradiol inhibits $\mathrm{GnRH}$ neuron firing in a subpopulation of cells. $\boldsymbol{D}, \mathrm{ICl} 182780$ blocks the inhibition in firing. $\boldsymbol{E}$, The ER $\beta$ agonist DPN has no effect on firing. $\boldsymbol{F}$, The ER $\alpha$ agonist PPT reversibly inhibits firing in a subpopulation of $G n R H$ neurons. G, Summary of spikes per minute responding cells (10 pm E, $n=9 ; \mathrm{ICl}, n=6 ; \mathrm{PPT}, n=6 ; \mathrm{DPN}, n=10) .{ }^{*} p<0.01$.
A
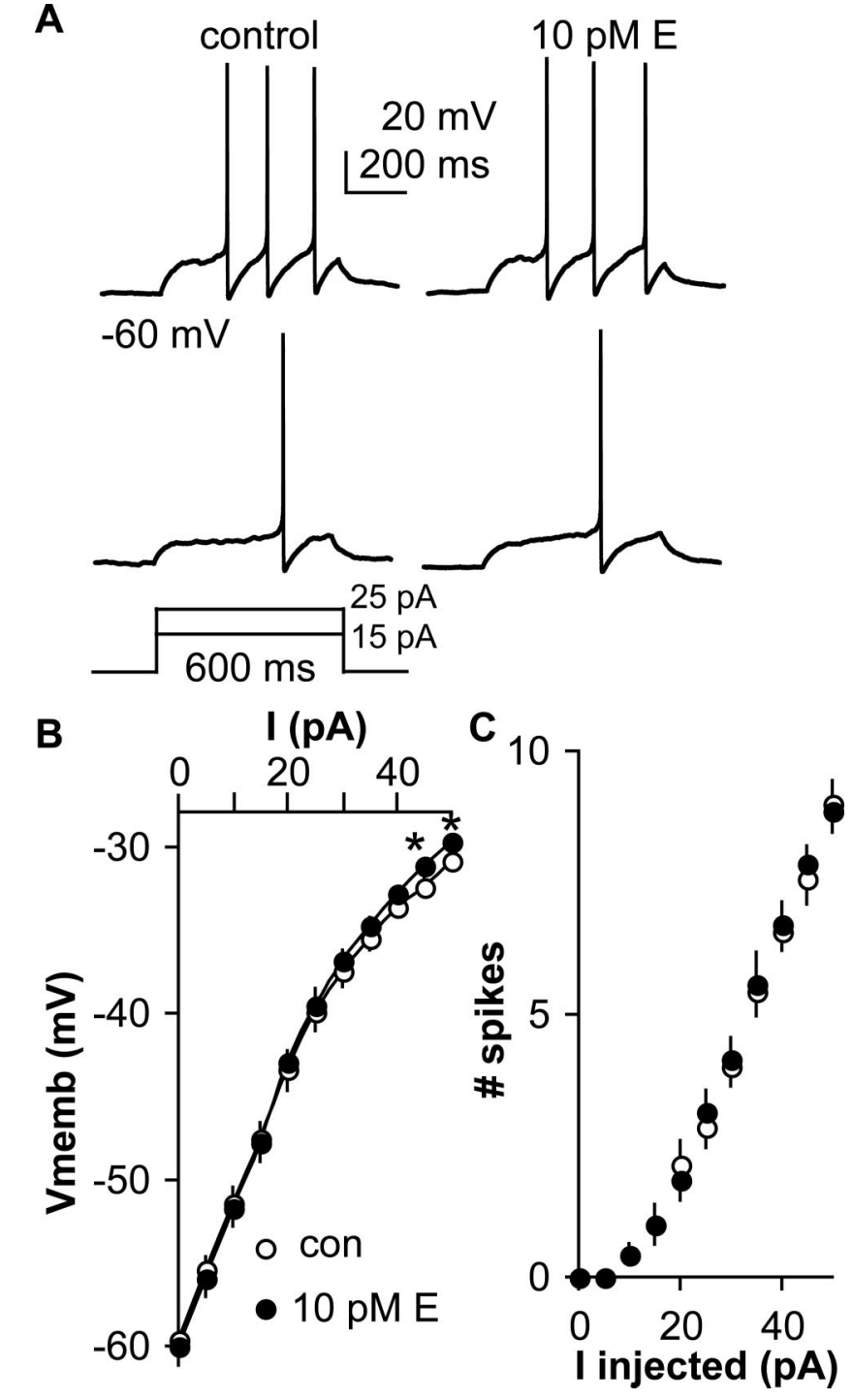

Figure 8. Picomolar concentrations of estradiol have no effect on intrinsic properties of $\mathrm{GnRH}$ neurons. $A$, Representative current-clamp recordings showing no effect of $10 \mathrm{pm}$ estradiol on $\mathrm{GnRH}$ neuron firing in response to injected current. $\boldsymbol{B}$, Mean \pm SEM membrane potential change in response to current injection $(n=8)$. C, Mean \pm SEM number of spike elicited during the control and 10 pм estradiol treatment periods for each current injection $(n=8)$.

romodulator release, indicating an intrinsic mechanism. Consistent with an intrinsic effect, an ER $\beta$ agonist mimicked the effect of nanomolar estradiol. $\operatorname{ER} \beta$, specifically $\operatorname{ER} \beta 2$, is expressed in $\mathrm{GnRH}$ neurons, whereas expression of $\mathrm{ER} \alpha$ in GnRH neurons is controversial (Radovick et al., 1991; Herbison and Pape, 2001; Hrabovszky et al., 2001; Navarro et al., 2003; Chung et al., 2007). The present data provide further evidence that intrinsic properties are not affected by this isoform. The percentage of $\mathrm{GnRH}$ neurons responding to nanomolar estradiol in the present study (70\%) is similar to that expressing $E R \beta$ in the rat $(67-73 \%)$ (Hrabovszky et al., 2001). Estradiol (1 nM) increased firing rate of cultured embryonic primate $\mathrm{GnRH}$ neurons with a similar time course in a manner dependent on classical estrogen receptors (Abe and Terasawa, 2005). In the same model, increased frequency and synchronization of oscillations in intracellular calcium concentrations were reported, but interestingly, these actions were not blocked by ICI182780 and were attributed to an integral membrane protein such as GPR30 (Abe et al., 2008). 
Similar to the present study, changes in intracellular calcium dynamics in cultured embryonic murine GnRH neurons and phosphorylation of CREB in GnRH neurons were dependent on $\mathrm{ER} \beta$, although the former, measured at $30 \mathrm{~min}$, was transcription dependent (Abrahám et al., 2003; Temple et al., 2004). These differences may be attributed to species, for example differences in the propagation of calcium waves (Moore et al., 2002; Abe et al., 2008) or to the different developmental stages of the cells (embryonic vs adult). In contrast to the excitatory responses in the above and present studies, 1-10 nM estradiol acutely hyperpolarized GnRH neurons and other hypothalamic cells in guinea pigs by opening an inwardly rectifying potassium channel (Kelly et al., 1984; Lagrange et al., 1995).

Mechanistically, $10 \mathrm{~nm}$ estradiol increased excitability, hyperpolarized action potential threshold, and inhibited the AHP and its underlying current. The effects on the AHP and $I_{\mathrm{AHP}}$ were occluded by previous blockade of $I_{\mathrm{KCa}}$, suggesting acute estradiol either inhibits calciumactivated potassium currents in $\mathrm{GnRH}$ neurons, as in the hippocampus and hypothalamus (Kelly et al., 2002; Carrer et al., 2003), or that estradiol decreases calcium conductances that subsequently activate $I_{\mathrm{KCa}}$ (Kumar and Foster, 2002). GnRH neurons (Jasoni et al., 2007) and GT1 GnRH neurons (Spergel, 2007) exhibit $I_{\mathrm{KCa}}$. Acute estradiol (1 nM) had no effect on $I_{\mathrm{KCa}}$ in GT1 cells, whereas a $3 \mathrm{~d}$ exposure increased expression of these channels and resulting current in an ER $\beta$ dependent manner (Nishimura et al., 2008). This difference may be attributed to mechanistic differences, with the longer treatment enabling changes in gene expression that alter current in the opposite direction of the nongenomic actions of an acute treatment. In this regard, however, in vivo treatment with estradiol for $2-4 \mathrm{~d}$

reduced the AHP in GnRH neurons to a similar extent as acute estradiol. Alternatively, the transformed and/or immature state of GT1 cells may alter response to estradiol. Here, $10 \mathrm{~nm}$ estradiol increased input resistance, further supporting a mechanism involving reduced membrane conductance.

In contrast to the marked excitatory effects of $10 \mathrm{~nm}$ estradiol, low physiological doses of estradiol (10 pM) did not affect GnRH neuron firing when ionotropic GABA and glutamate receptors were blocked to reduce slice network interactions. When network interactions were left intact, however, a subpopulation of $\mathrm{GnRH}$ neurons was inhibited by $10 \mathrm{pM}$ estradiol in an ER $\alpha$-mediated response. The relative lack of evidence for ER $\alpha$ expression in adult GnRH neurons, the lack of effect of $10 \mathrm{pm}$ estradiol on any examined intrinsic properties of GnRH neurons, and the need for network interactions for a response suggest this inhibitory action of $10 \mathrm{pm}$ estradiol is synaptically mediated. Consistent with this, stimulatory drive via GABAergic transmission was acutely inhibited by an $\mathrm{ER} \alpha$ agonist. Interestingly, $100 \mathrm{~nm}$ estradiol increased GABA transmission in ER $\beta \mathrm{KO}$ mice, implying involvement of $\mathrm{ER} \alpha$ (Romanò et al., 2008). A small percentage of $\mathrm{GnRH}$ neurons were affected in that study, and the timing was delayed relative to the present study, but this illustrates the complex temporal nature of estradiol regulation of GnRH neurons, even in acute in vitro studies.

With network interactions intact, approximately half of GnRH neurons were still excited by $10 \mathrm{~nm}$ estradiol. An ER $\beta$ agonist had no overall effect on firing rate in this paradigm but did increase GABA transmission and amplitude of GABAergic PSCs, which, like the ER $\beta$-mediated effects on intrinsic properties, should be stimulatory. This dissociation between the effect of $10 \mathrm{nM}$ estradiol and the $\mathrm{ER} \beta$-specific agonist suggests $\operatorname{ER} \beta$ may alter additional network interactions that inhibit GnRH neurons. 
Estradiol alters spinyness synaptic transmission (Woolley and McEwen, 1992; Gu and Moss, 1996; Rudick and Woolley, 2003) and may act directly on secretory vesicles (Hart et al., 2007).

A pure classical estrogen receptor antagonist blocked both inhibitory and stimulatory effects of acute estradiol. Furthermore, these effects were mimicked by agonists of $\mathrm{ER} \alpha$ and $\mathrm{ER} \beta$, respectively, but not by a GPR30 agonist, indicating rapid estradiol effects on murine GnRH neurons are mediated by classical receptors, rather than GPR30, ERX, or other membrane estrogen receptors (Toran-Allerand et al., 2002; Qiu et al., 2003; Bologa et al., 2006). The pure estrogen $\mathrm{ER} \alpha / \beta$ ICI antagonist had no stimulatory effect alone, further supporting the lack of a role of GPR30 in this system (Prossnitz et al., 2008). In neuronal systems, estradiol initiates signaling via kinase cascades, including PKA, MAPK, and phospholipase C-protein kinase C ( $\mathrm{Gu}$ and Moss, 1996; Zhou et al., 1996; Watters et al., 1997; Qiu et al., 2003). In some neurons, rapid actions of estradiol appear to involve activation of type- 1 metabotropic glutamate receptors (mGluR1s) (Boulware et al., 2005). In cultured embryonic rat GnRH neurons and GT1 cells, picomolar estradiol acted via ER $\alpha$ to reduce cAMP accumulation, whereas nanomolar estradiol activated cAMP accumulation, a dose dependence with interesting parallels to the present results (Navarro et al., 2003). Our initial studies indicate blocking PKA eliminated the excitatory effects of $1 \mathrm{~nm}$ estradiol in GnRH neurons, suggesting involvement of PKA, but not excluding participation of other signaling pathways. Future work will determine if mGluRs are involved; although previous work indicated no direct effect of mGluR1 agonists in $\mathrm{GnRH}$ neurons, parameters examined were related to the response to GABAergic transmission rather than other intrinsic properties (Chu and Moenter, 2005).

$\mathrm{ER} \beta$, which mediates the direct effects estradiol on $\mathrm{GnRH}$ neurons, has been considered to be less critical to reproductive success than ER $\alpha$ (Couse and Korach, 1999; Wintermantel et al., 2006). ER $\beta$ mice, however, are suboptimally fertile, and although ovarian effects are often cited as the reason for this, central modulatory roles for $\operatorname{ER} \beta$ that are important for full fertility may exist. Although interaction of ER $\alpha$ with estrogenresponse elements appears essential for generating the increased activity of $\mathrm{GnRH}$ neurons during positive feedback (Christian et al., 2008), this does not preclude a supporting role for $\mathrm{ER} \beta$ to further increase $\mathrm{GnRH}$ neuron activity during a time when many parallel excitatory pathways appear to be (Christian et al., 2005; Christian and Moenter, 2008a,b; Clarkson et al., 2008). Another consideration is that ER $\beta$ activation and thus GnRH neuron activity may be enhanced by increased central synthesis of estradiol (Hojo et al., 2004; ToranAllerand et al., 2005). Of interest, circulating estrogen is elevated in women with polycystic ovary syndrome, a pathology associated with increased GnRH neuron activity (Yen et al., 1976; Eagleson et al., 2003). This concept of changes in local synthesis of estradiol opens a novel and intriguing mechanism to take into consideration in future studies. Circulating estradiol changes during the female reproductive cycle, peaking at high picomolar levels during the preovulatory period, and remaining at low picomolar levels during the majority of the cycle. Our finding that the rapid response to estradiol changes direction from inhibitory to excitatory within the physiological range of this steroid by engaging different receptor subtypes and neurobiological mechanisms, suggests these rapid actions are poised to play a contributing role to the overall feedback action of estradiol.

\section{References}

Abe H, Terasawa E (2005) Firing pattern and rapid modulation of activity by estrogen in primate luteinizing hormone releasing hormone-1 neurons. Endocrinology 146:4312-4320.

Abe H, Keen KL, Terasawa E (2008) Rapid action of estrogens on intracellular calcium oscillations in primate LHRH-1 neurons. Endocrinology 149:1155-1162.

Abrahám IM, Han SK, Todman MG, Korach KS, Herbison AE (2003) Estrogen receptor beta mediates rapid estrogen actions on gonadotropinreleasing hormone neurons in vivo. J Neurosci 23:5771-5777.

Abrahám IM, Todman MG, Korach KS, Herbison AE (2004) Critical in vivo roles for classical estrogen receptors in rapid estrogen actions on intracellular signaling in mouse brain. Endocrinology 145:3055-3061.

Barry PH (1994) JPCalc, a software package for calculating liquid junction potential corrections in patch-clamp, intracellular, epithelial and bilayer measurements and for correcting junction potential measurements. J Neurosci Methods 51:107-116.

Bologa CG, Revankar CM, Young SM, Edwards BS, Arterburn JB, Kiselyov AS, Parker MA, Tkachenko SE, Savchuck NP, Sklar LA, Oprea TI, Prossnitz ER (2006) Virtual and biomolecular screening converge on a selective agonist for GPR30. Nat Chem Biol 2:207-212.

Boulware MI, Weick JP, Becklund BR, Kuo SP, Groth RD, Mermelstein PG (2005) Estradiol activates group 1 and group II metabotropic glutamate receptor signaling, leading to opposing influences on cAMP response element-binding protein. J Neuorsci 25:5066-5078.

Bryant W, Snowhite AE, Rice LW, Shupnik MA (2005) The estrogen receptor (ER) alpha variant delta-5 exhibits dominant positive activity on ERregulated promoters in endometrial carcinoma cells. Endocrinology 146:751-759.

Carrer HF, Araque A, Buño W (2003) Estradiol regulates the slow $\mathrm{Ca}^{2+}$ activated $\mathrm{K}^{+}$current in hippocampal pyramidal neurons. J Neurosci 23:6338-6344.

Christian CA, Moenter SM (2007) Estradiol induces diurnal shifts in GABA transmission to gonadotropin-releasing hormone neurons to provide a neural signal for ovulation. J Neurosci 27:1913-1921.

Christian CA, Moenter SM (2008a) Critical roles for fast synaptic transmission in mediating estradiol negative and positive feedback in the neural control of ovulation. Endocrinology 149:5500-5508.

Christian CA, Moenter SM (2008b) Vasoactive intestinal polypeptide can excite gonadotropin-releasing hormone neurons in a manner dependent on estradiol and gated by time of day. Endocrinology 149:3130-3136.

Christian CA, Mobley JL, Moenter SM (2005) Diurnal and estradioldependent changes in gonadotropin-releasing hormone neuron firing activity. Proc Natl Acad Sci U S A 102:15682-15687.

Christian CA, Glidewell-Kenney C, Jameson JL, Moenter SM (2008) Classical estrogen receptor alpha signaling mediates negative and positive feedback on gonadotropin-releasing hormone neuron firing. Endocrinology 149:5328-5334.

Christian CA, Pielecka-Fortuna J, Moenter SM (2009) Estradiol suppresses glutamatergic transmission to gonadotropin-releasing hormone neurons in a model of negative feedback in mice. Biol Reprod. Advance online publication. Retrieved April 6, 2009. doi: 10.1095/biolreprod.108.075077.

Chu Z, Moenter SM (2005) Endogenous activation of metabotropic glutamate receptors modulates GABAergic transmission to gonadotropinreleasing hormone neurons and alters their firing rate: a possible local feedback circuit. J Neurosci 25:5740-5749.

Chu Z, Moenter SM (2006) Physiologic regulation of a tetrodotoxinsensitive sodium influx that mediates a slow afterdepolarization potential in gonadotropin-releasing hormone neurons: possible implications for the central regulation of fertility. J Neurosci 26:11961-11973.

Chung WC, Pak TR, Suzuki S, Pouliot WA, Andersen ME, Handa RJ (2007) Detection and localization of an estrogen receptor beta splice variant protein (ERbeta2) in the adult female rat forebrain and midbrain regions. J Comp Neurol 505:249-267.

Clarke IJ, Cummins JT (1982) The temporal relationship between gonadotropin releasing hormone $(\mathrm{GnRH})$ and luteinizing hormone $(\mathrm{LH})$ secretion in ovariectomized ewes. Endocrinology 111:1737-1739.

Clarkson J, d'Anglemont de Tassigny X, Moreno AS, Colledge WH, Herbison AE (2008) Kisspeptin-GPR54 signaling is essential for preovulatory gonadotropin-releasing hormone neuron activation and the luteinizing hormone surge. J Neurosci 28:8691-8697. 
Couse JF, Korach KS (1999) Estrogen receptor null mice: what have we learned and where will they lead us? Endocr Rev 20:358-417.

DeFazio RA, Heger S, Ojeda SR, Moenter SM (2002) Activation of A-type (gamma)-aminobutyric acid receptors excites gonadotropin-releasing hormone neurons. Mol Endocrinol 16:2872-2891.

Döcke F, Dörner G (1965) The mechanism of the induction of ovulation by oestrogens. J Endocrinol 33:491-499.

Eagleson CA, Bellows AB, Hu K, Gingrich MB, Marshall JC (2003) Obese patients with polycystic ovary syndrome: evidence that metformin does not restore sensitivity of the gonadotropin-releasing hormone pulse generator to inhibition by ovarian steroids. J Clin Endocrinol Metab $88: 5158-5162$.

Filardo EJ, Thomas P (2005) GPR30: a seven-transmembrane-spanning estrogen receptor that triggers EGF release. Trends Endocrinol Metab 16:362-367.

Glass CK (1994) Differential recognition of target genes by nuclear receptor monomers, dimers, and heterodimers. Endocr Rev 15:391-407.

Gu Q, Moss RL (1996) $17 \beta$-estradiol potentiates kainate-induced currents via activation of the cAMP cascade. J Neurosci 16:3620-3629.

Han SK, Todman MG, Herbison AE (2004) Endogenous GABA release inhibits the firing of adult gonadotropin-releasing hormone neurons. Endocrinology 145:495-499.

Harrington WR, Sheng S, Barnett DH, Petz LN, Katzenellenbogen JA, Katzenellenbogen BS (2003) Activites of estrogen receptor alpha- and betaselective ligands at diverse estrogen responsive gene sites mediating transactivation or transrepression. Mol Cell Endocrinol 206:13-22.

Hart SA, Snyder MA, Smejkalova T, Woolley CS (2007) Estrogen mobilizes a subset of estrogen receptor- $\alpha$-immunoreactive vesicles in inhibitory presynaptic boutons in hippocampal CA1. J Neurosci 27:2102-2111.

Heldring N, Pike A, Andersson S, Matthews J, Cheng G, Hartman J, Tujague M, Ström A, Treuter E, Warner M, Gustafsson JA (2007) Estrogen receptors: how do they signal and what are their targets? Physiol Rev 87:905-931.

Herbison AE (1998) Multimodal influence of estrogen upon gonadotropinreleasing hormone neurons. Endocr Rev 19:302-330.

Herbison AE, Pape JR (2001) New evidence for estrogen receptors in gonadotropin-releasing hormone neurons. Front Neuroendocrinol 22:292-308.

Herbison AE, Skynner MJ, Sim JA (2001) Erratum: lack of detection of estrogen receptor-alpha transcripts in mouse gonadotropin releasinghormone neurons. Endocrinology 142:493.

Hojo Y, Hattori TA, Enami T, Furukawa A, Suzuki K, Ishii HT, Mukai H, Morrison JH, Janssen WG, Kominami S, Harada N, Kimoto T, Kawato S (2004) Adult male rat hippocampus synthesizes estradiol from pregnenolone by cytochromes P45017 alpha and P450 aromatase localized in neurons. Proc Natl Acad Sci U S A 101:865-870.

Hrabovszky E, Shughrue PJ, Merchenthaler I, Hajszán T, Carpenter CD, Liposits Z, Petersen SL (2000) Detection of estrogen receptor-beta messenger ribonucleic acid and 125I-estrogen binding sites in luteinizing hormone-releasing hormone neurons of the rat brain. Endocrinology 141:3506-3509.

Hrabovszky E, Steinhauser A, Barabás K, Shughrue PJ, Petersen SL, Merchenthaler I, Liposits Z (2001) Estrogen receptor-beta immunoreactivity in luteinizing hormone-releasing hormone neurons of the rat brain. Endocrinology 142:3261-3264.

Jasoni CL, Todman MG, Strumia MM, Herbison AE (2007) Cell typespecific expression of a genetically encoded calcium indicator reveals intrinsic calcium oscillations in adult gonadotropin-releasing hormone neurons. J Neurosci 27:860-867.

Kelly MJ, Ronnekleiv OK, Eskay RL (1984) Identification of estrogenresponsive LHRH neurons in the guinea pig hypothalamus. Brain Res Bull 12:399-407.

Kelly MJ, Rønnekleiv OK, Ibrahim N, Lagrange AH, Wagner EJ (2002) Estrogen modulation of $\mathrm{K}(+)$ channel activity in hypothalamic neurons involved in the control of the reproductive axis. Steroids 67:447-456.

Kumar A, Foster TC (2002) 17beta-estradiol benzoate decreases the AHP amplitude in CA1 pyramidal neurons. J Neurophysiol 88:621-626.

Kushner PJ, Agard DA, Greene GL, Scanlan TS, Shiqu AK, Uht RM, Webb P (2000) Estrogen receptor pathways to AP-1. Steroid Biochem Mol Biol 74:313-317.

Lagrange AH, Rønnekleiv OK, Kelly MJ (1995) Estradiol-17 beta and mu- opioid peptides rapidly hyperpolarize GnRH neurons: a cellular mechanism of negative feedback? Endocrinology 136:2341-2344.

Levine JE, Duffy MT (1988) Simultaneous measurement of luteinizing hormone (LH)-releasing hormone, $\mathrm{LH}$, and follicle-stimulating hormone release in intact and short-term castrate rats. Endocrinology 122:2211-2221

Levine JE, Pau KY, Ramirez VD, Jackson GL (1982) Simultaneous measurement of luteinizing hormone-releasing hormone and luteinizing hormone release in unanesthetized, ovariectomized sheep. Endocrinology 111:1449-1455.

Moenter SM, DeFazio RA (2005) Endogenous gamma-aminobutyric acid can excite GnRH neurons. Endocrinology 146:5374-5379.

Moenter SM, Caraty A, Locatelli A, Karsch FJ (1991) Pattern of gonadotropin-releasing hormone $(\mathrm{GnRH})$ secretion leading up to ovulation in the ewe: existence of a preovulatory GnRH surge. Endocrinology 129:1175-1182.

Moenter SM, Brand RM, Midgley AR, Karsch FJ (1992) Dynamics of gonadotropin-releasing hormone release during a pulse. Endocrinology 130:503-510.

Moenter SM, DeFazio AR, Pitts GR, Nunemaker CS (2003) Mechanisms underlying episodic gonadotropin-releasing hormone secretion. Front Neuroendocrinol 24:79-93.

Moore JP Jr, Shang E, Wray S (2002) In situ GABAergic modulation of synchronous gonadotropin releasing hormone-1 neuronal activity. J Neurosci 22:8932-8941.

Navarro CE, Saeed SA, Murdock C, Martinez-Fuentes AJ, Arora KK, Krsmanovic LZ, Catt KJ (2003) Regulation of cyclic adenosine 3',5'monophosphate signaling and pulsatile neurosecretion by Gi-coupled plasma membrane estrogen receptors in immortalized gonadotropinreleasing hormone neurons. Mol Endocrinol 17:1792-1804.

Nethrapalli IS, Singh M, Guan X, Guo Q, Lubahn DB, Korach KS, ToranAllerand CD (2001) Estradiol (E2) elicits SRC phosphorylation in the mouse neocortex: the initial event in $\mathrm{E} 2$ activation of the MAPK cascade? Endocrinology 142:5145-5148.

Nishimura I, Ui-Tei K, Saigo K, Ishii H, Sakuma Y, Kato M (2008) 17 \{beta\}estradiol at physiological concentrations augments $\mathrm{Ca} 2+$-activated $\mathrm{K}+$ currents via estrogen receptor $\{$ beta $\}$ in the gonadotropin-releasing hormone neuronal cell line GT1-7. Endocrinology 149:774-782.

Nunemaker CS, DeFazio RA, Moenter SM (2002) Estradiol-sensitive afferents modulate long-term episodic firing patterns of GnRH neurons. Endocrinology 143:2284-2292.

Nunemaker CS, DeFazio RA, Moenter SM (2003) A targeted extracellular approach for recording long-term firing patterns of excitable cells: a practical guide. Biological Procedures Online 5:53-62.

Prossnitz ER, Arterburn JB, Smith HO, Oprea TI, Sklar LA, Hathaway HJ (2008) Estrogen signaling through the transmembrane G proteincoupled receptor GPR30. Annu Rev Physiol 70:165-190.

Qiu J, Bosch MA, Tobias SC, Grandy DK, Scanlan TS, Ronnekleiv OK, Kelly MJ (2003) Rapid signaling of estrogen in hypothalamic neurons involves a novel G-protein-coupled estrogen receptor that activates protein kinase C. J Neurosci 23:9529-9540.

Radovick S, Ticknor CM, Nakayama Y, Notides AC, Rahman A, Weintraub BD, Cutler GB Jr, Wondisford FE (1991) Evidence for direct estrogen regulation of the human gonadotropin-releasing hormone gene. J Clin Invest 88:1649-1655.

Revankar CM, Cimino DF, Sklar LA, Arterburn JB, Prossnitz ER (2005) A transmembrane intracellular estrogen receptor mediates rapid cell signaling. Science 307:1625-1630.

Romanò N, Lee K, Abrahám IM, Jasoni CL, Herbison AE (2008) Nonclassical estrogen modulation of presynaptic GABA terminals modulates calcium dynamics in gonadotropin-releasing hormone neurons. Endocrinology 149:5335-5344.

Roy D, Angelini NL, Belsham DD (1999) Estrogen directly respresses gonadotropin-releasing hormone $(\mathrm{GnRH})$ gene expression in estrogen receptor-alpha (ERalpha)- and ERbeta-expressing GT1-7 GnRH neurons. Endocrinology 140:5045-5053.

Rudick CN, Woolley CS (2003) Selective estrogen receptor modulators regulate phasic activation of hippocampal CA1 pyramidal cells by estrogen. Endocrinology 144:179-187.

Sabbah M, Courilleau D, Mester J, Redeuilh G (1999) Estrogen induction of the cyclin D1 promoter: involvement of a cAMP response-like element. Proc Natl Acad Sci U S A 96:11217-11222. 
Skynner MJ, Sim JA, Herbison AE (1999) Detection of estrogen receptor alpha and beta messenger ribonucleic acids in adult gonadotropinreleasing hormone neurons. Endocrinology 140:5195-5201.

Song RX, McPherson RA, Adam L, Bao Y, Shupnik M, Kumar R, Santen RJ (2002) Linkage of rapid estrogen action to MAPK activation by ER \{alpha\}-Shc association and Shc pathway activation. Mol Endocrinol $16: 116-127$.

Spergel DJ (2007) Calcium and small-conductance calcium-activated potassium channels in gonadotropin-releasing hormone neurons before, during and after puberty. Endocrinology 148:2383-2390.

Sun J, Baudry J, Katzenellenbogen JA, Katzenellenbogen BS (2003) Molecular basis for the subtype discrimination of the estrogen receptor- $\beta$ selective ligand, diarylpropionitrile. Mol Endocrinol 17:247-258.

Suter KJ (2004) Control of firing by small (S)-alpha-amino-3-hydroxy-5methyl-isoxazolepropionic acid-like inputs in hypothalamic gonadotropin releasing-hormone (GnRH) neurons. Neuroscience 128:443-450.

Suter KJ, Song WJ, Sampson TL, Wuarin JP, Saunders JT, Dudek FE, Moenter SM (2000) Genetic targeting of green fluorescent protein to gonadotropin-releasing hormone neurons: characterization of whole-cell electrophysiological properties and morphology. Endocrinology 141:412-419.

Temple JL, Laing E, Sunder A, Wray S (2004) Direct action of estradiol on gonadotropin-releasing hormone-1 neuronal activity via a transcriptiondependent mechanism. J Neurosci 24:6326-6333.

Toran-Allerand CD, Guan X, MacLusky NJ, Horvath TL, Diano S, Singh M, Connolly ES Jr, Nethrapalli IS, Tinnikov AA (2002) ER-X: a novel, plasma membrane-associated, putative estrogen receptor that is regulated during development and after ischemic brain injury. J Neurosci 22:8391-8401.
Toran-Allerand CD, Tinnikov AA, Singh RJ, Nethrapalli IS (2005) 17\{alpha\}-estradiol: a brain-active estrogen? Endocrinology 146:3843-3850.

Vivacqua A, Bonofiglio D, Recchia AG, Musti AM, Picard D, Andò S, Maggiolini M (2006) The G protein-coupled receptor GPR30 mediates the proliferative effects induced by $17\{$ beta\}-estradiol and hydroxytamoxifen in endometrial cancer cells. Mol Endocrinol 20:631-646.

Watters JJ, Campbell JS, Cunningham MJ, Krebs EG, Dorsa DM (1997) Rapid membrane effects of steroids in neuroblastoma cells: effects of estrogen on mitogen activated protein kinase signalling cascade and c-fos immediate early gene transcription. Endocrinology 138:4030-4033.

Wintermantel TM, Campbell RE, Porteous R, Bock D, Gröne HJ, Todman MG, Korach KS, Greiner E, Pérez CA, Schütz G, Herbison AE (2006) Definition of estrogen receptor pathway critical for estrogen positive feedback to gonadotropin-releasing hormone neurons and fertility. Neuron 52:271-280.

Woolley CS (2007) Acute effects of estrogen on neuronal physiology. Annu Rev Pharmacol Toxicol 47:657-680.

Woolley CS, McEwen BS (1992) Estradiol mediates fluctuation in hippocampal synapse density during the estrous cycle in the adult rat. J Neurosci 12:2549-2554.

Yen S, Chaney C, Judd H (1976) Functional abberations of the hypothalamic-pituitary system in PCOS-a consideration for pathogenesis. New York: Academic.

Yin C, Ishii H, Tanaka N, Sakuma Y, Kato M (2008) Activation of A-type gamma-amino butyric acid receptors excites gonadotrophin-releasing hormone neurons isolated from adult rats. J Neuroendocrinol 20:566-575.

Zhou Y, Watters JJ, Dorsa DM (1996) Estrogen rapidly induces the phosphorylation of the cAMP response element binding protein in rat brain. Endocrinology 137:2163-2166. 